\title{
A BRIEF OVERVIEW OF THE CORN BIOREFINERY IN BRAZIL
}

Artur Santos Bispo ${ }^{a}$, Leonardo Oliveira Santos de Santanaa, Gustavo de Souza dos Santos ${ }^{a}$, Erika Durão Vieira ${ }^{a}$

a , Centro Universitario SENAI CIMATEC, Brazil

\begin{abstract}
An overview about corn culture in Brazil is presented and a biorefinery concept based on this crop is proposed in light of the International Energy Agency (IEA) policies. The biorefinery proposal comprises 3 platforms and 6 products based on one feedstock, the corn grain. A flowchart was designed and the biorefinery complexity index $(\mathrm{BCl})$ was calculated based on IEA TASK 42 . The focus was the corn oil platform which produces tocopherols, an important feedstock for vitamin $\mathrm{E}$, a high added value product compared to the others. The waste material was directed to animal feed and biogas. Biodiesel, glycerin and bioethanol are the other important products obtained from this corn grain biorefinery.
\end{abstract}

Keywords: Corn; Biorefinery; Tocopherols; biorefinery complexity index.

\section{UMA BREVE REVISÃO DA BIOREFINARIA DE MILHO NO BRASIL}

Resumo: É apresentada uma visão geral sobre a cultura do milho no Brasil e um conceito de biorrefinaria baseado neste cultivar é proposto à luz das políticas da Agência Internacional de Energia (AIE). A proposta da biorrefinaria compreende 3 plataformas e 6 produtos baseados no grão de milho como matéria-prima. Foi elaborado um fluxograma e calculado o índice de complexidade das biorrefinarias $(\mathrm{BCl})$ com base no IEA TASK 42. O foco da proposta foi a plataforma de óleo de milho, que produz tocoferóis, uma importante matéria-prima para a vitamina $E$, um produto de alto valor agregado em comparação com os outros. Os resíduos foram direcionados para ração animal e biogás. Biodiesel, glicerina e bioetanol são outros produtos importantes obtidos nesta biorrefinaria de grãos de milho.

Palavras-chave: Milho; biorrefinaria; tocoferóis; índice de complexidade da biorrefinaria. 


\section{INTRODUCTION}

Brazil $(101 \mathrm{kton} / \mathrm{y})$ is the third largest corn producer in the world, behind China (366 kton/y) and the USA ( $257 \mathrm{kton} / \mathrm{y})$. China has a large population and consumes more corn than it can produce. On the other hand, $50 \%$ of the brazilian corn production is exported. Corn is consumed worldwide as feed and food products but other high value-added products could be obtained from its industrial processing. A new horizon of untapped possibilities can be designed to the maize culture ${ }^{[1] .}$

Corn crop plantations in Brazil has been increasing as well as productivity per land area unit since 1997, as shown in figure 1. Climate and soil conditions are very favorable, especially in the southern states that leads the ranking of the largest producers in Brazil [2] [3].

Figure 1. Brazilian Production and Cultivate area of corn (1997-2019)

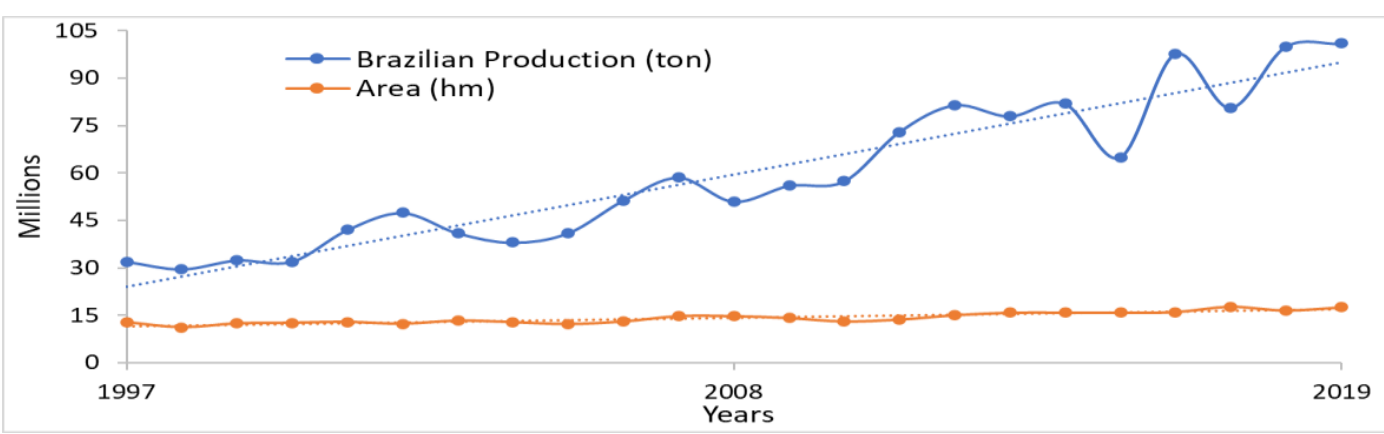

Source: Adapted from Embrapa (2014); IBGE (2019) [3] [2] [4] [1]

In an international view, according to EMBRAPA, the corn can be considered one of the most important commercial plants of all American continent. This importance is due the diversity of ways that corn can be used for, it goes from animal feed to Hightech industry. In fact, the use of corn grain for animal feed represents $70 \%$ of the consumption of this cereal ${ }^{[2]}$

Still in a global market perspective, analyzing the last 20 years, according to the graph in figure 2, can be seen a high price growth of corn (about $469,95 \%$ ) that goes from $R \$ 137.59$ (per ton) in July-2000, to $\mathrm{R} \$ 771.11$ (per ton) in June-2020. Besides, 2020 registered the highest price of the cereal in this time interval, reaching $R \$ 813.32$ (per ton) in May-2020 [5].

Figure 2: Maize Monthly Price - Brazilian Real per Ton

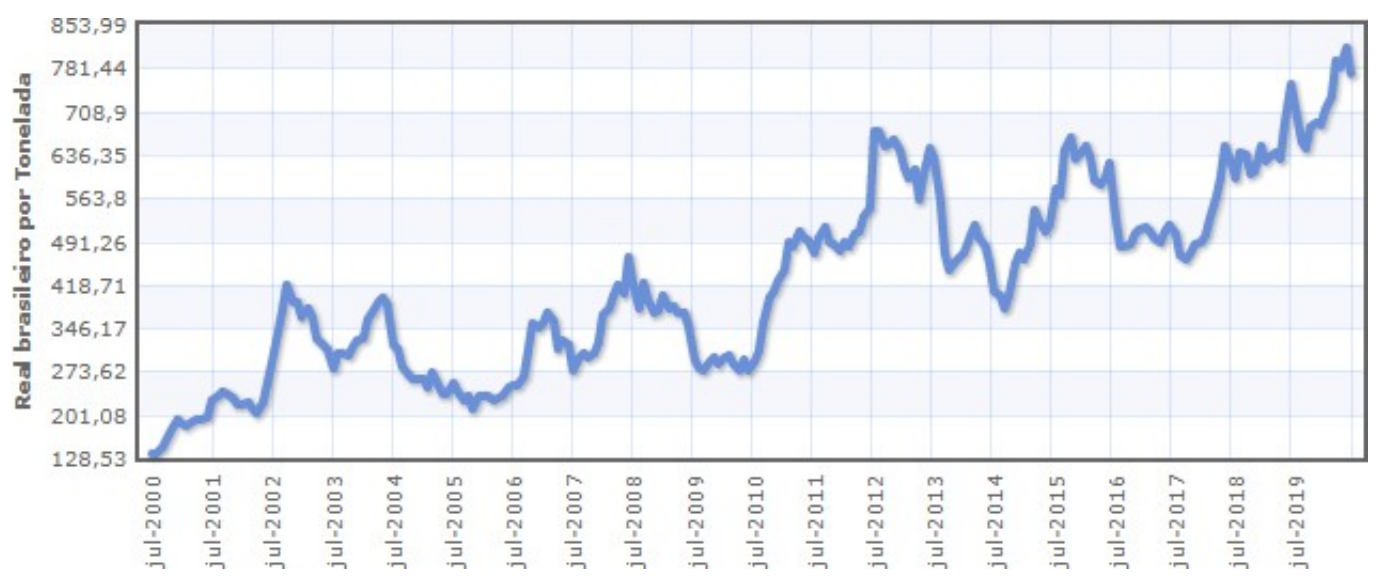

Source: Index Mundi [5] 


\subsection{Corn wet-milling}

After harvesting, grain is separated from the corn cob and subjected to classification operations. The stages of grains processing are: pre-cleaning, cleaning, classification, the grains go through a gravity table that is separated by the specific weight and, finally, a treatment in which the seeds are separated by length. After that, the seeds are packaged and stored for further processing which includes separation operations into its major components: oil, meal and fiber. Table 1 shows the derived products from corn, the main process to obtain these products are the wet milling process ${ }^{[7]}$.

Table 1. Corn-derived products and its applications

\begin{tabular}{|c|c|c|}
\hline \multicolumn{3}{|c|}{ Corn-Derived Products } \\
\hline Steep water & \multicolumn{2}{|c|}{ Chemicals, pharmaceuticals, yeast culture, biogas } \\
\hline \multirow[t]{2}{*}{ Germ } & Oil & Vitamin carriers, lecithin, cooking oil, biodiesel \\
\hline & Meal & Livestock feed, amino acids, fur cleaner \\
\hline Fiber & \multicolumn{2}{|r|}{ Feed, cattle feed } \\
\hline Protein & \multicolumn{2}{|r|}{ Feed, poultry feed } \\
\hline \multirow{3}{*}{ Starch } & Food & $\begin{array}{l}\text { Bakery products, beverages, sauces, puddings, } \\
\text { snack foods, chocolate drinks, candies, prepared } \\
\text { condiments, baby foods, etc. }\end{array}$ \\
\hline & Industrial & $\begin{array}{l}\text { Detergents, cleaners, paper products, adhesives, } \\
\text { ceramics, textiles, plastic molding, printing inks, } \\
\text { colloid emulsions, chemicals, etc. }\end{array}$ \\
\hline & Sweeteners & $\begin{array}{l}\text { Alcoholic beverages, amino acids, industrial } \\
\text { alcohols, fuels, polyols, sugars }\end{array}$ \\
\hline
\end{tabular}

Source: Rausch, K. D., 2019 [6]

The conventional Wet-Milling process consists of, basically, six different steps: Grain handling; Steeping; Germ separation and washing; Fiber separation and recovery; Gluten separation and recovery; Starch separation and recovery. These steps make up the flowsheet in figure 3. According to Ramirez et al. (2008), the steps can be described as follows ${ }^{[7]}$.

Figure 3: Simplified flowsheet - Wet milling process

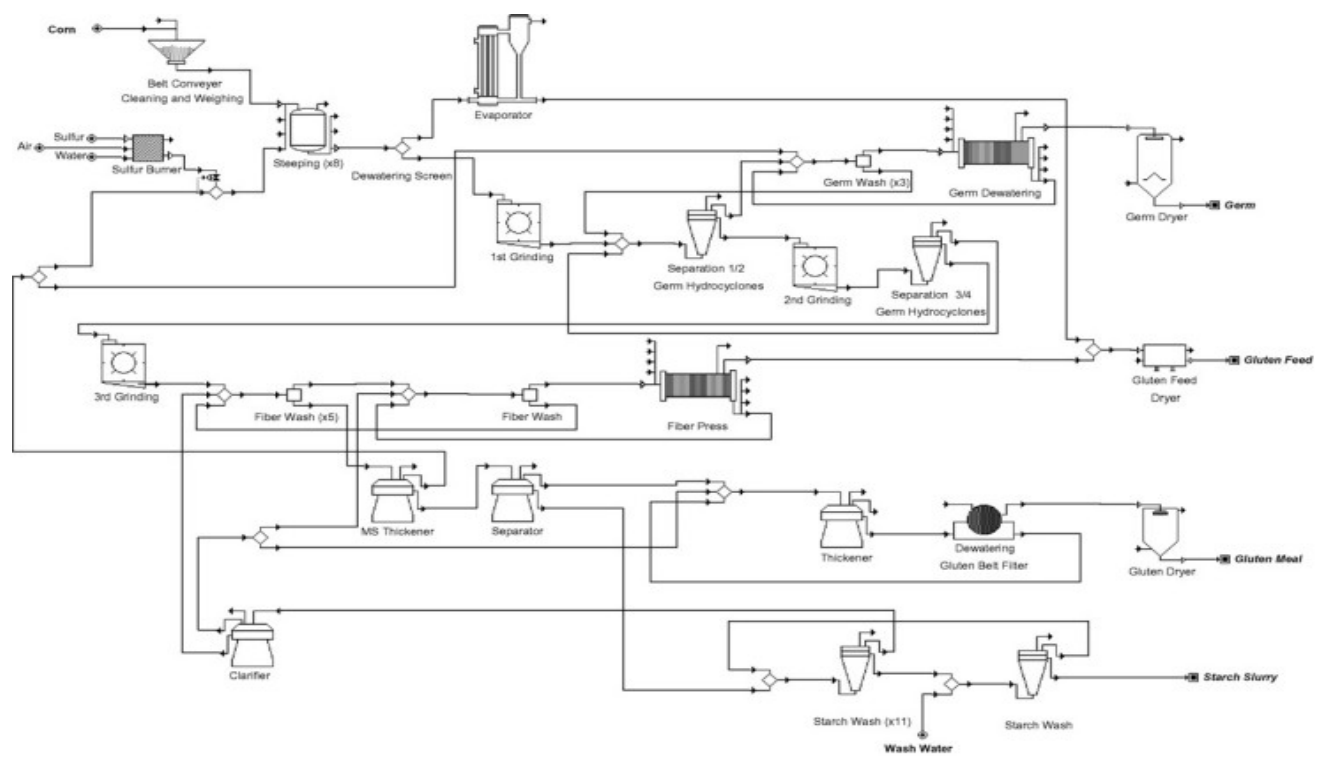


Source: Ramirez et al. (2008) ${ }^{[7]}$

Primarily, to prevent clogging the screens, increasing viscosity during the process, and affecting the final product quality, foreign matters are removed from the corn. Thereafter, the cleaning corn are sent to Steeping.

Steeping is the stage of the chemical process in which the protein matrix is broken to release starch granules, so that they can be removed in other stages, in order to facilitate separation, cleaning the corn and, therefore, increasing the content of grain moisture, removing soluble impurities [6].

The germ is removed from the kernel after a course grinding. The kernel is ground and the corn germ - which is rich in oil - is separated from the starch slurry using four sets of hydrocyclones (based on the lower density of the germ compared to the slurry). Afterward, the germ is recovered from the first set of hydrocyclones while the underflow goes to another set. After those process of separation, the remained slurry is recovered by the last two sets of cyclones [6].

The corn slurry from the last step pass into a grift screen to separate water, loose starch and gluten from the fiber, bound starch and gluten. Then, those last ones are ground to finalize the dispersion of the starch. Posteriorly, ground slurry is washed and separated in a set of tanks and fiber wash screens (in countercurrent). The wash water carries the free starch and gluten, and the clean fiber is recovered after a process of dehydration, passing through a screen and screw press [7].

The gluten separation process is performed in a disk stack centrifuge by density difference. However, before this process the starch should be degraded to remove all impurities as possible, in order not to interfere with the centrifuges later in the process. Then, the mill starch is concentrated, to facilitate the separation in the mill-starch thickener. The Thickener stream is sent to the primary centrifuge and a separation process happens by density difference, in order to obtain a high-quality gluten [7].

The crude starch is washed by a set of smalls hydrocyclones and grouped in different stages, in countercurrent. Throughout the starch washing, the underflow is sent to the posteriorly stage while overflow is recycled to the previous stage. The water that carries the impurities is recycled back to the middling clarifier to furthers process of fiber and gluten separation [6].

Therefore, this work aims to propose a corn biorefinery that comprises 3 platforms and 6 products based on one feedstock, the corn grain. A flowchart was designed and the biorefinery complexity index $(\mathrm{BCl})$ was calculated based on IEA TASK 42. The focus was the corn oil platform which produces tocopherols. The waste material was directed to animal feed and biogas.

\section{METHODOLOGY}

A bibliographic review on corn crop production and grain processing scenario in Brazil and worldwide was made. Data were collected from open source platforms as Google Scholar and governmental institutions websites as EMBRAPA, IEA, DOE. The keywords used to the state-of-the-art search were: corn, maize, crop, grain, production, process, biorefinery, Brazil, wet milling, dry milling.

From this review, the corn wet milling process was pointed out as the most promising existing industrial process to be the basis of the biorefinery proposal of the 
present work. The corn grain biorefinery proposal is a type III biorefinery, that is a Multiple, highly integrated and flexible processes allowing conversion of multiple feedstocks of a different or the same nature into a highly diverse portfolio of products. Flexible biorefineries will allow switching between feedstocks and blending of feedstocks for conversion into products. The present biorefinery proposal includes, besides the production of food and feed products, the production of fuels (biodiesel, ethanol and biogas) and of tocopherols [8].

An example of a flowsheet and $\mathrm{BCl}$ according to IEA TASK 42 for an oilseed crops, like soybean is presented below. as we can see, it's a low complexity biorefinery type 1 , with 1 feedstock and no variable products.

Figure 4: Oilseed crops refinery (flowsheet and $\mathrm{BCl}$ )
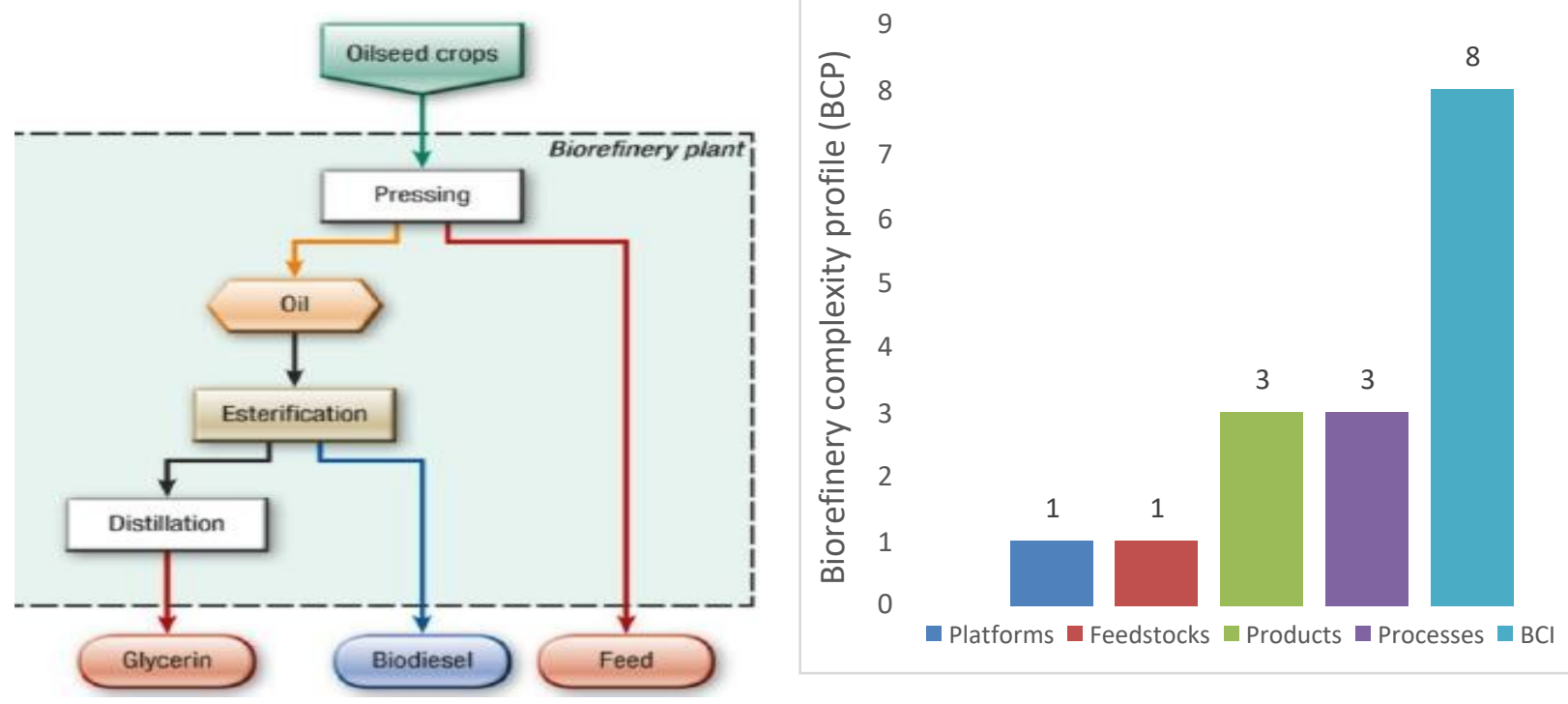

Source: Jungmeier (2014) ${ }^{[9]}$

A flowsheet based on the IEA TASK 42 was made, this flowsheet takes into account four features of biorefinery (feedstock, platform, processes, products). The biorefinery complexity index $(\mathrm{BCl})$ was calculated based on the classification system of biorrefineries proposed by the International Energy Agency (IEA). BCl was developed by IEA based on and "Nelson's complexity index" for oil refineries. For each of the four features of biorefinery (feedstock, platform, processes, products) the technology readiness level (TRL) is assessed using a level description between 1 ("basic research") to 9 ("system proven and ready for full commercial deployment"). Based on the TRL the feature complexity (FC) for each single feature of a biorefinery is calculated $\left(\mathrm{FCi}=10-T R \mathrm{~L}_{\mathrm{i}}\right)$. and the $\mathrm{BCl}$ is calculated as seen in equation 1 , below [9].

$$
B C I=\sum_{i=}^{4} F C l i=\sum^{4} \quad \sum_{j=1}^{m} N F i j
$$

\section{RESULTS AND DISCUSSION}

The proposed biorefinery is presented on figure 5 . The whole corn grain is the only feedstock used. The first operational step is the separation of the parts of the grain through the wet milling. First the steeping phase the dry corn is introduced in a steep tank and soaked in steepwater, later, the soaked grain and the steepwater are separated. The second part is the separation between the germ and fiber followed by separation between starch and protein. Steep water and the wastewater from the fiber 
press, germ press and fermentation are degradated by anaerobic digestion, and produces biogas ${ }^{[8]}$.

Dry fiber, dry germ and protein become feedstock for animal feed and the starch and oil from germ become feedstock to C6 (6-carbon chain sugars) and corn oil platform. These are the most important platforms, while biogas platform and solid waste produces low added value products, the C6 and corn oil may be the most important feedstocks to corn biorefinery ${ }^{[8]}$.

These platforms can produce a very wide range of products, but in this example the focus will be on fuels and pharmaceuticals. Starch can be hydrolyzed to form fermentable sugars; ethanol is the most common product. On the corn oil platform, the oil extracted from the germ can be refined and the tocopherols can be extracted, the fatty acids of the oil can transformed into diesel and glycerol ${ }^{[8]}$.

Figure 5. Flowchart for classification of corn biorefinery (IEA)

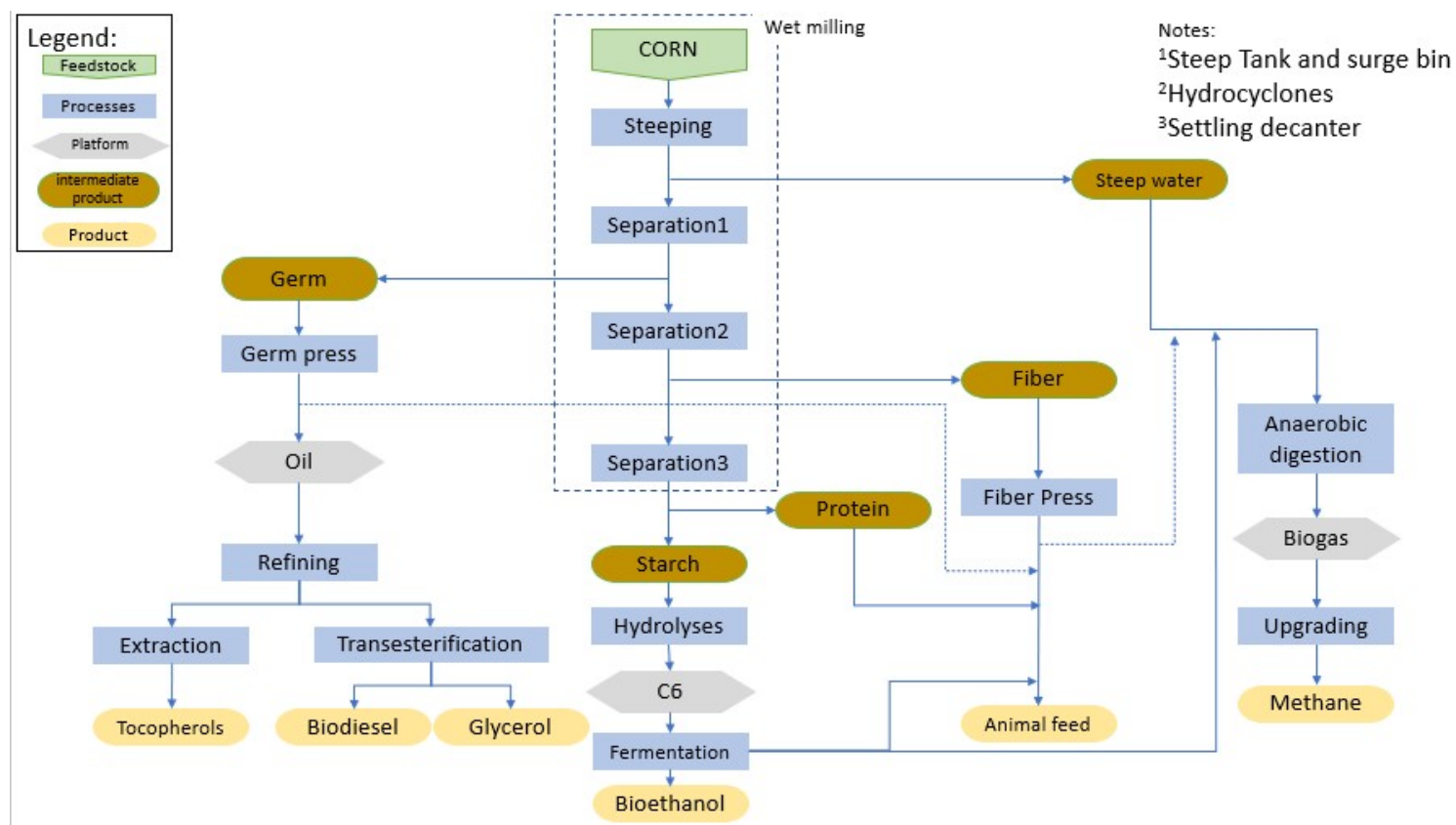

The $\mathrm{BCl}$ for the present proposal can be calculated from equation 1 , as we can see in figure 6 . the $\mathrm{BCl}$ for this example is 33 , which is relatively high, considering that the proposed biorefinery produces 6 products, including products with a high added value such as tocopherol ${ }^{[9]}$.

Figure 6. Biorefinery Complexity Profile (BCP)

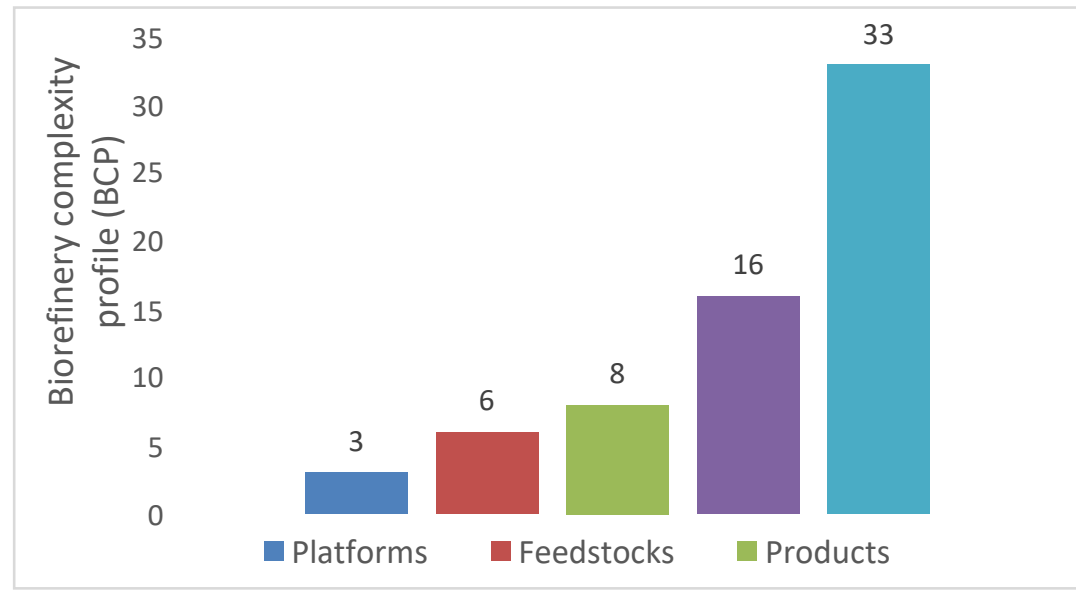


The TRL for each process is shown below (figure 7) and, as we can see, most items have a TRL of 9 (proven system and ready for full commercial deployment). if we divide the $\mathrm{BCl}$ for each product, the average number is 5.3. this means that the proposed biorefinery has a low Capex cost for each possible product ${ }^{[9]}$.

Figure 7. Technology readiness level (TRL)

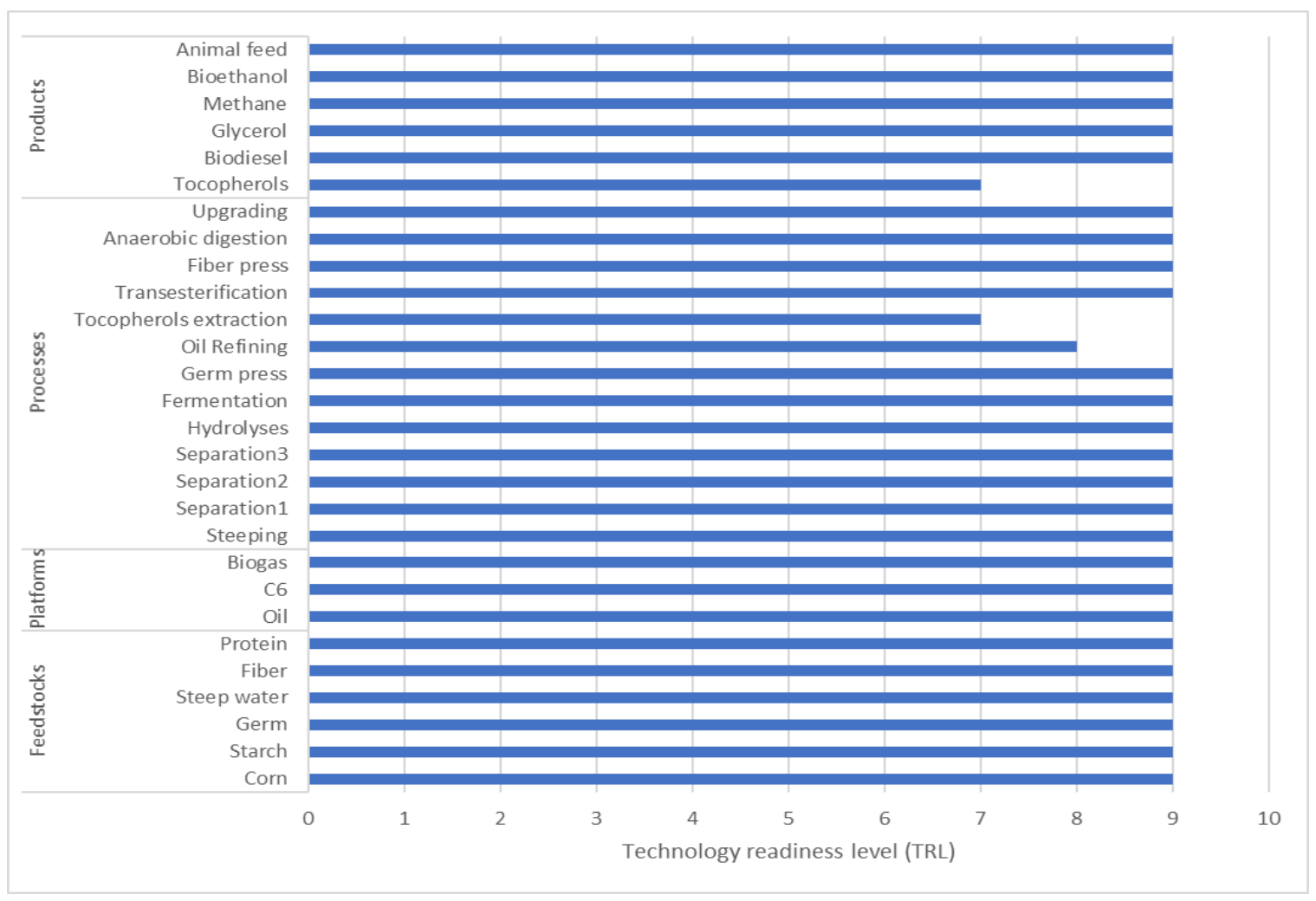

\section{CONCLUSION}

The Brazilian scenario of corn production is very promising, with an increasing productivity per planted area and the growth of production in the country, who has become the third biggest corn producer in the world. The biorefinery possibilities has been becoming a very interesting way to increase the added value. Besides fuel and feeding appliances, pharmacist products, like tocopherols, are a good opportunity of product without a large increase of $\mathrm{BCl}$.

\section{REFERENCES}

${ }^{1}$ Federação das industrias do estado de São Paulo, "Safra mundial de milho 2019/20- $3^{\circ}$ levantamento do USDA," USDA, 2019. [Online]. Available:

https://www.fiesp.com.br/indices-pesquisas-e-publicacoes/safra-mundial-de-milho2/attachment/file-20190715143626-boletimmilhojulho2019/. [Acesso em 1506 2020].

2Embrapa, "Cultivo do milho: Economia da produção," Embrapa, 2015. [Online]. Available:

https://www.spo.cnptia.embrapa.br/conteudo?p_p_id=conteudoportlet_WAR_siste masdeproducaolf6_1ga1ceportlet\&p_p_lifecycle $=0 \& p \_p \_s t a t e=n o r m a l \& p \_p \_$mode $=v i e w \& p \_p \_c o l \_i d=$ column-1\&p_p_col_count=1\&p_r_p_- 
76293187_sistemaProducaold=7905\&p_r_p_-996514994_topicold=8. [Acesso em 1506 2020].

${ }^{3}$ IBGE-Instituto brasileiro de geografia e estatística, "SIDRA," IBGE, 092019. [Online]. Available: https://sidra.ibge.gov.br/Tabela/1612. [Acesso em 0508 2020].

${ }^{4}$ PIONEER, "O milho no Brasil, sua importância e evolução," 2014. [Online].

Available: http://www.pioneersementes.com.br/media-center/artigos/165/o-milhono-brasil-sua-importancia-e-evolucao. [Acesso em 1506 2020].

${ }^{5}$ Index mundi, "Indices de preçoes: Milho preço mensal-real brasileiro por tonelada," 06 2020. [Online]. Available: https://www.indexmundi.com/pt/pre\%C3\%A7os-demercado/?mercadoria=milho\&meses $=240 \&$ moeda=brl. [Acesso em 0508 2020].

${ }^{6}$ K. D. Rausch, D. Hummel, L. A. Johnson e J. B. May, "Wet Milling: The Basis for Corn," em Corn, Elsevier, 2019.

${ }^{7}$ D. B. J. A. J. M. W. Y. V. S. Edna C. Ramirez, "Engineering process and cost model for a conventional corn," vol. 67, 2008.

${ }^{8} \mathrm{~J}$. Sadhukhan, K. S. NG e E. M. Hernandez, Biorefineries and chemical processes: Design, integration and sustainability analysis, John Wiley \& Sons, 2014.

${ }^{9} \mathrm{G}$. Jungmeier, "The biorefinery complexity index," 09072014. 